\title{
Kinerja Modulus Resilien Campuran Beraspal Panas Asphalt Concrete Binder Course (AC-BC) Yang Mengandung Recycled Concrete Aggregate
}

\author{
Galih Wulandari Subagyo \\ Fakultas Teknologi dan Desain, Program Studi Teknik Sipil \\ Universitas Pembangunan Jaya, Tangerang Selatan, Banten 15413, Indonesia \\ galih.wulandari@upj.ac.id
}

Received 22 November 2019, Revised 11 December 2019, Accepted 21 December 2019

\begin{abstract}
$\overline{\text { Abstract - Construction activities require a small amount of stone or sand material, so }}$ construction activities are directly in conflict with environmental conservation which has the intent and purpose of preserving or protecting nature. These conservation issues are a powerful driver in the development of asphalt pavement technology to obtain durable, inexpensive and environmentally friendly pavements including in Indonesia, which certainly minimizes the destruction of nature, one of which is by using waste materials for new road pavement that has been done a lot. One of the waste materials that will be tried to replace the new aggregate in this research is concrete waste. Concrete waste variation 0\%, 5\%, 10\%, 15\% of the total new aggregate. Then the test is carried out by the marshall test method (Marshall test data, marshall immersion and absolute density obtained from previous studies) to the resilient modulus test so that the Marshall characteristics are obtained along with the results of resilient modulus. Recycle Concrete Aggregate (RCA) derived from K-250 quality concrete (ex compressive strength testing) meets the requirements as an aggregate of hot asphalt mixtures based on the 2010 Bina Marga Specifications (Revision 3). Resistant modulus of AC-BC mixture containing Recycled Concrete Aggregate (RCA) is superior compared to without Recycled Concrete Aggregate (RCA) at three test temperatures of $25^{\circ} \mathrm{C}, 35^{\circ} \mathrm{C}, 45^{\circ} \mathrm{C}$.
\end{abstract}

Keywords: Asphalt Binding Course, Concrete Recycling Aggregate, Resilient Modulus Characteristics

\begin{abstract}
Abstrak - Aktivitas konstruksi membutuhkan material batu maupun pasir yang tidak sedikit jumlahnya, maka secara langsung aktivitas konstruksi bertentangan dengan konservasi lingkungan yang mempuyai maksud dan tujuan untuk pelestarian ataupun perlindungan alam. Isu-isu tentang konservasi tersebut merupakan pendorong yang kuat dalam pengembangan teknologi perkerasan aspal untuk memperoleh perkerasan yang awet, murah dan ramah lingkungan termasuk di Indonesia, yang tentunya meminimalisir adanya perusakan alam, salah satunya dengan menggunakan bahan limbah untuk perkerasan jalan yang baru sudah banyak dilakukan. Salah satu bahan limbah yang akan dicoba untuk mengganti agregat baru pada penelitian ini yaitu limbah beton. Variasi limbah beton $0 \%, 5 \%, 10 \%, 15 \%$ terhadap total agregat baru. Kemudian dilakukan pengujian terhadap benda uji tersebut dengan metode marshall test (data pengujian tes Marshall, rendaman marshall dan kepadatan mutlak didapatkan dari penelitian terdahulu) sampai dengan uji modulus resilien sehingga didapat hasil karakteristik Marshall berserta hasil dari modulus resilien. Limbah beton yang di gunakan berasal dari beton mutu K-250 (sisa pengujian kuat tekan) telah memenuhi persyaratan sebagai agregat campuran aspal panas berdasarkan Spesifikasi Bina Marga Tahun 2010 Divisi 6 (Revisi 3). Terhadap nilai modulus resilien campuran AC-BC yang mengandung Limbah beton lebih superior dibandingkan dengan tanpa limbah beton di tiga temperatur pengujian $25^{\circ} \mathrm{C}, 35^{\circ} \mathrm{C}, 45^{\circ} \mathrm{C}$.
\end{abstract}

Kata kunci: Asphalt Concrete Binder Course, Recycle Concrete Aggregate, Karakteristik Modulus Resilien

\section{PENDAHULUAN}

Aktivitas konstruksi membutuhkan material batu maupun pasir yang tidak sedikit jumlahnya, maka secara langsung aktivitas konstruksi bertentangan dengan konservasi lingkungan yang mempuyai maksud dan tujuan untuk pelestarian ataupun perlindungan alam. Isu-isu tentang konservasi tersebut merupakan pendorong yang kuat dalam 
pengembangan teknologi perkerasan aspal untuk memperoleh perkerasan yang awet, murah dan ramah lingkungan termasuk di Indonesia, yang tentunya meminimalisir adanya perusakan alam.

Melihat permasalahan tersebut di dalam penelitian ini mencoba hal lain yaitu menggunakan agregat yang berasal dari limbah beton bekas uji kuat tekan K250 yang terdapat di Laboratorium Univesitas Trisakti. Menurut Isyak Bayu Muhammad, 2016 bahwa berdasarkan hasil penelitian diperoleh penambahan limbah beton yang optimum adalah $8 \%$ terhadap total agregat kasar dan masuk pada spesifikasi Bina Marga 2010 Divisi 6 Revisi 3. Pada gambar 1 menunjukan limbah beton mutu K250.

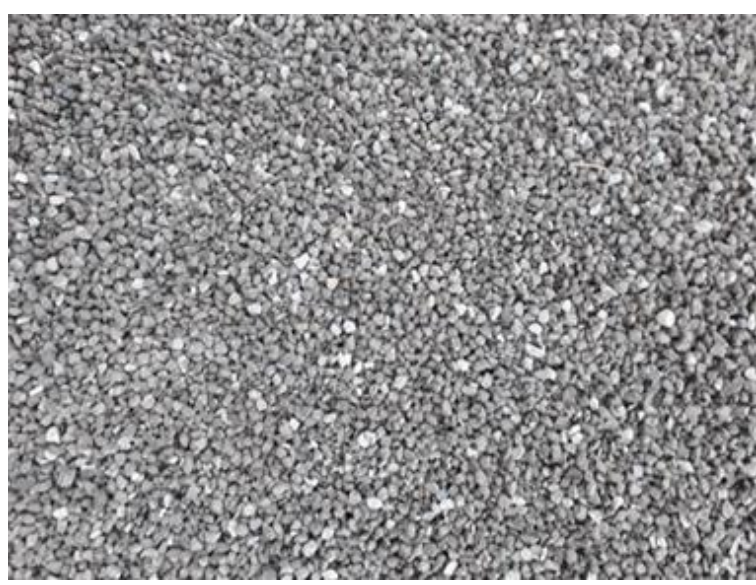

Gambar 1. Limbah Beton Mutu K250

Dalam penelitian ini difokuskan kepada tujuan tentang pengaruh limbah beton pada campuran beraspal panas pada gradasi (AC-BC) terhadap nilai kekakuan. Hasil yang diharapkan dalam penelitian ini adalah sebagai langkah untuk mendapatkan alternatif pemilihan penggunaan agregat dalam perencanaan perkerasan jalan di wilyah Indonesia serta sebagai bahan informasi kepada Pemerintah tentang penggunaan limbah beton dalam perancangan campuran AC-BC. Penelitian ini dibatasi oleh Perkerasan lentur yang ditinjau adalah campuran Laston Lapis Antara (AC-BC). Untuk material yang digunakan adalah aspal Pen 60/70 Shell. Gradasi yang digunakan pada penelitian ini hanya menggunakan satu jenis variasi gradasi campuran Laston Lapis Antara (AC - BC). Material agregat kasar, agregat medium dan abu batu yang digunakan sebagai bahan campuran perkerasan adalah material yang berasal dari Loji Sungai Cigentis Provinsi Jawa Barat. Limbah beton yang digunakan adalah sisa bekas uji kuat tekan mutu K250 yang terdapat di Laboratorium Univesitas Trisakti, persentase limbah beton yang digunakan bervariasi sebagai berikut:

- $\quad 0 \%$ terhadap berat total agregat baru.

- $5 \%$ terhadap berat total agregat baru.

- $10 \%$ terhadap berat total agregat baru.

- $15 \%$ terhadap berat total agregat baru.
Standar pengujian karakteristik agregat dan aspal didasarkan pada Spesifikasi Umum Campuran Beraspal Panas (Kementerian Pekerjaan Umum Tahun 2010 Divisi 6 Revisi 3), Standar Nasional Indonesia (SNI). Perencanaan campuran aspal panas menggunakan metode Marshall dan pendekatan kepadatan mutlak untuk mendapatkan Kadar Aspal Optimum (KAO) dengan menggunakan data dari peneliti terdahulu. Analisis untuk mendapatkan nilai modulus resilien menggunakan bantuan alat UMATTA (Universal Material Testing Apparatus).

\section{Beton Aspal}

Teknologi pelapisan aspal dengan cara mencampur terlebih dahulu agregat dengan aspal pada temperatur panas, kemudian baru digelar dalam kondisi panas atau dingin dan dipadatkan hingga mencapai kepadatan tertentu adalah beton aspal. Jika pemadatan telah selesai untuk dapat digunakan pada lalu lintas umum maka suhu permukaan haruslah berada dibawah $60^{\circ} \mathrm{C}$. Ada beberapa keuntungan menggunakan beton aspal yaitu pelaksanaan pekerjaan akan lebih cepat, kepadatan lapisan mudah tercapai, aspal akan meningkat sifat tahan terhadap panasnya karena tercampur dengan filler (Van Dormon, 1953, dalam Ir. Soehartono, 2015).

\section{Laston}

Menurut Bina Marga Tahun 2010 Divisi 6 Revisi 3 untuk campuran beton aspal terdiri atas aspal keras dan agregat bergradasi menerus yang dicampur, dihamparkan, dan dipadatkan dalam keadaan panas pada temperatur tertentu. Jenis dan karakteristik aspal yang digunakan adalah untuk menentukan temperatur pencampurannya. Gradasi menerus adalah Pembagian butir yang merata mulai dari ukuran yang terbesar hingga ukuran terkecil (Rindu Twidi Bethary, 2018).

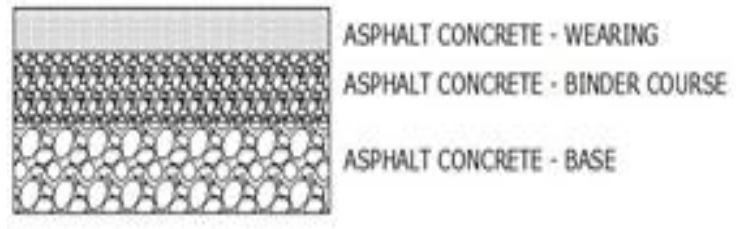

Gambar 2. Konstruksi Lapisan Pondasi Atas (Base), Lapisan Pengikat (Binder Course) dan Lapisan Permukaan (Wearing Course)

Adapun karakteristik campuran ini dapat dilihat pada Tabel 1 di bawah ini dimana berdasarkan referensi dari Bina Marga divisi 6, 2010 (Revisi 3), minimum stablitas Marshall yang diperlukan adalah $800 \mathrm{~kg}$.

\section{Aspal}

Menurut Sukirman, 2003 aspal adalah material berbentuk padat dan bersifat termoplastis apabila material tersebut pada temperatur ruang. Bila dipanaskan sampai temperatur tertentu maka aspal 
akan mencair dan akan kembali membeku jika temperatur turun.

Tabel 1. Ketentuan Karakteristik Campuran AC-BC gradasi kasar (Bina Marga divisi 6, 2010, Revisi 3)

Sifat-sifat Campuran Spec. AC-BC Gradasi Kasar

Jumlah tumbukan Per

bidang

Rasio partikel lolos ayakan

$0,075 \mathrm{~mm}$ dengan kadar

aspal efektif

Rongga dalam campuran

$(\%)$

Rongga dalam agregat

(VMA) (\%)

Rongga terisi aspal (VFB)

$(\%)$

Stabilitas Marshall (kg)

Pelelehan (mm)

Stabilitas marshall sisa

setelah perendaman 24 jam,

$60^{\circ} \mathrm{C}$

Rongga dalam campuran

(\%) pada kepadatan

membel (refusal)

$\begin{array}{lc} & 75 \\ \text { Min. } & 1,0 \\ \text { Maks. } & 1,4 \\ \text { Min. } & 3,0 \\ \text { Maks. } & 5,0 \\ \text { Min. } & 14 \\ \text { Min. } & 65 \\ \text { Min. } & 800 \\ \text { Min. } & 3 \\ \text { Maks. } & 5 \\ \text { Min. } & 90\end{array}$

Min.

2

\section{Aspal}

Menurut Sukirman, 2003 aspal adalah material berbentuk padat dan bersifat termoplastis apabila material tersebut pada temperatur ruang. Bila dipanaskan sampai temperatur tertentu maka aspal akan mencair dan akan kembali membeku jika temperatur turun.

Tabel 2. Hasil Pemeriksaan Aspal (Hasil penelitian dan Bina Marga, 2010, Revisi 3)

\begin{tabular}{|c|c|c|c|c|}
\hline No. & JENIS PENGUJIAN & $\begin{array}{c}\text { METODA } \\
\text { PENGUJIAN }\end{array}$ & $\begin{array}{c}\text { NILAI } \\
\text { PERSYARAAN } \\
\text { DARI BINA } \\
\text { MARGA 2014 } \\
\end{array}$ & $\begin{array}{c}\text { HASIL } \\
\text { PENGUJAN }\end{array}$ \\
\hline 1. & Penetrasi Pada $25^{\circ} \mathrm{C}(0,1 \mathrm{~mm})$ & SNI 06-2456-1991 & $60-70$ & 64 \\
\hline 2. & Penetrasi Pada $35^{\circ} \mathrm{C}(0,1 \mathrm{~mm})$ & SNI 06-2456-1991 & $\cdot$ & 159,2 \\
\hline 3. & Penetrasi Pada $45^{\circ} \mathrm{C}(0,1 \mathrm{~mm})$ & SNI 06-2456-1991 & $\cdot$ & 224,2 \\
\hline \multirow[t]{3}{*}{4.} & \begin{tabular}{|l|l} 
Viskositas Saybolt Furol \\
\end{tabular} & & & \\
\hline & \begin{tabular}{|l|l|} 
Suhu Pemadatan Ideal \\
\end{tabular} & \multirow{2}{*}{$\begin{array}{c}\text { AASHTO T72-90 } \\
\text { dan AASHTO T54-6 }\end{array}$} & & $140^{\circ} \mathrm{C}$ \\
\hline & \begin{tabular}{|l|} 
Suhu Pencampuran Ideal \\
\end{tabular} & & & $150^{\circ} \mathrm{C}$ \\
\hline 5. & Titik lembek ( $\left.{ }^{\circ} \mathrm{C}\right)$ & SNI 2434:2011 & $\geq 48^{\circ} \mathrm{C}$ & $50,5^{\circ} \mathrm{C}$ \\
\hline 6. & Daktilitas $25^{\circ} \mathrm{C},(\mathrm{cm})$ & SNI 2432:2011 & $\geq 100 \mathrm{~cm}$ & $>100 \mathrm{~cm}$ \\
\hline 7. & Tititk Nyala $\left({ }^{\circ} \mathrm{C}\right)$ & SNI 2433:2011 & $\geq 232^{\circ} \mathrm{C}$ & $355^{\circ} \mathrm{C}$ \\
\hline 8. & \begin{tabular}{|l} 
Kelarutan dalam \\
Trichloroethylene (\%)
\end{tabular} & AASHTO T44-03 & $\geq 99 \%$ & $99,95 \%$ \\
\hline 9. & Berat Jenis & SNI 2441:2001 & $\geq 1,0$ & 1,026 \\
\hline \multicolumn{5}{|c|}{ Pengujian Residu Hasil TFOT (SNI-06-2240-1991) atau RTFOT (SNI-03-6835-2002) : } \\
\hline 10. & Berat yang hilang $(\%)$ & SNI 06-2441-1991 & $\leq 0,8 \%$ & $0,0068 \%$ \\
\hline 11. & Penetrasi Pada $25^{\circ} \mathrm{C}(0,1 \mathrm{~mm})$ & SNI 06-2456-1991 & $\geq 54$ & 61,60 \\
\hline 12. & Penetrasi Pada $35^{\circ} \mathrm{C}(0,1 \mathrm{~mm})$ & SNI 06-2456-1991 & . & 135 \\
\hline 13. & Penetrasi Pada $45^{\circ} \mathrm{C}(0,1 \mathrm{~mm})$ & SNI 06-2456-1991 & $\cdot$ & 176 \\
\hline 14. & Daktilitas pada $25^{\circ} \mathrm{C}(\mathrm{cm})$ & SNI 2432:2011 & $\geq 100 \mathrm{~cm}$ & $>100 \mathrm{~cm}$ \\
\hline 15. & Titik Lembek ${ }^{\circ} \mathrm{C}$ & & . & $56,5^{\circ} \mathrm{C}$ \\
\hline
\end{tabular}

\section{Agregat}

Bahan utama untuk struktur jalan adalah agregat, dimana yang dimaksud dengan agregat tersebut adalah Sekumpulan butir batu pecah dan pasir / mineral lain, baik hasil dari alam maupun buatan. Lapis perkerasan mengandung 90-95\% agregat berdasarkan persen berat campuran atau $75-85 \%$ agregat berdasarkan persen volume campuran. Untuk menggunakan agregat agar tidak menggurangi kinerja campuran harus dalam kondisi bersih dari kotoran, bahan-bahan organik/ bahan lain yang tidak dikehendaki (Hardiyatmo, 2011).

Tabel 3. Hasil Pemeriksaan Agregat Baru (Hasil penelitian dan Bina Marga, 2010, Revisi 3)

\begin{tabular}{|c|c|c|c|c|c|c|c|}
\hline No. & PENGUUIAN & METODA & \multicolumn{4}{|c|}{ HASIL PENGUUIAN } & $\begin{array}{c}\text { NILAI } \\
\text { PERSYARA } \\
\text { TN BINA } \\
\text { MARGA } \\
2010\end{array}$ \\
\hline 1. & $\begin{array}{l}\text { Kekekalan bentuk agregat } \\
\text { terhadap larutan NaSO4 } \\
\text { atau MgSO4 }\end{array}$ & SNI 3407:2008 & \multicolumn{4}{|c|}{$2,16 \%$} & Maks. $12 \%$ \\
\hline 2. & $\begin{array}{l}\text { Abrasi dengan mesin Los } \\
\text { Angles }\end{array}$ & SNI 2417:2008 & \multicolumn{4}{|c|}{$24,25 \%$} & Maks. $30 \%$ \\
\hline 3. & \begin{tabular}{|lr}
$\begin{array}{l}\text { Kelekatan } \\
\text { terhadap aspal }\end{array}$ & agregat \\
\end{tabular} & SNI $2439: 2011$ & \multicolumn{4}{|c|}{$99 \%$} & Min. $95 \%$ \\
\hline 4. & $\begin{array}{l}\text { Butir Pecah Pada Agregat } \\
\text { Kasar }\end{array}$ & SNI 7619:2012 & \multicolumn{4}{|c|}{$95 \%$} & $95 / 90 *)$ \\
\hline 5. & Kadar Lumpur & $\begin{array}{c}\text { SNI-S-04- } \\
1998 F, 1989 \\
\end{array}$ & \multicolumn{4}{|c|}{$3,51 \%$} & $\leq 5 \%$ \\
\hline \multirow{2}{*}{6.} & Partikel Pipih & ASTM D4791 & \multicolumn{4}{|c|}{$7,83 \%$} & Maks. $10 \%$ \\
\hline & $\begin{array}{l}\text { Partikel Kelonjongan } \\
\end{array}$ & & \multicolumn{4}{|c|}{$8,39 \%$} & Maks. $10 \%$ \\
\hline \multirow[t]{12}{*}{7.} & Berat Jenis & \multirow{12}{*}{$\begin{array}{c}\text { SNI 03-1969- } \\
1990\end{array}$} & Bulk & SSD & App & Abs & \\
\hline & $\begin{array}{l}\text { Ukuran Saringan I" } \\
\end{array}$ & & & & & & \multirow{11}{*}{$\begin{array}{l}\text { - Absorbsi } \\
<3 \% \\
\text { - Perbedaan } \\
\text { agregat kasar } \\
\text { dan agregat } \\
\text { halus }<0,2 \%\end{array}$} \\
\hline & Ukuran Saringan 3/4" & & 2,63 & 2,68 & 2,67 & 1,82 & \\
\hline & Ukuran Saringan $1 / 2$ " & & $\frac{2,00}{2,62}$ & 2,60 & 2,76 & $\frac{1,02}{1,88}$ & \\
\hline & $\begin{array}{l}\text { Ukuran Sanding } \\
\text { Ukun } 3 / 8^{\prime \prime}\end{array}$ & & $\frac{2,02}{2.57}$ & $\frac{2,01}{2,60}$ & $\begin{array}{l}2,70 \\
2,61\end{array}$ & $\frac{1,00}{1,35}$ & \\
\hline & Ukuran Saringan No. 4 & & 263 & 2,68 & 275 & 1,67 & \\
\hline & Ukuran Saringan No. 8 & & 2,59 & 2,60 & 2,61 & \begin{tabular}{|lll}
, 01 \\
\end{tabular} & \\
\hline & Ukuran Saringan No. 16 & & 2,63 & 2,66 & 2,70 & - & \\
\hline & Ukuran Saringan No.30 & & 2,62 & 2,63 & 2,66 & - & \\
\hline & Ukuran Saringan No. 50 & & 2,58 & 2,59 & 2,60 & - & \\
\hline & Ukuran Saringan No. 100 & & 2,65 & 2,60 & 2,69 & - & \\
\hline & Uluran Sariogan No 200 & & $\frac{265}{265}>0>0$ & 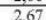 & 271 & - & \\
\hline
\end{tabular}

Amplop Gradasi Agregat Gabungan untuk Campuran Aspal AC Lapis Antara/AC-BC. Gradasi campuran ACBC yang selanjutnya disebut campuran HMA dirancang dengan memperhatikan batasan yang ditetapkan dalam Spesifikasi Umum Jalan dan Jembatan Bina Marga Tahun 2010 (Revisi 3). Rancangan gradasi dalam penelitian ini dipilih terletak di atas kurva Fuller (gradasi halus), dimana diharapkan adanya keseragaman yang lebih baik pada penimbangan untuk masing-masing contoh uji/sampel (Indramaha, 2015). Rancangan dan kurva gradasi dapat dilihat pada Tabel 4 dan Gambar 3.

Tabel 4. Persyaratan gradasi agregat (Bina Marga divisi 6, 2010, Revisi 3)

\begin{tabular}{|c|c|c|c|c|c|c|}
\hline \multirow[t]{2}{*}{ No } & \multicolumn{2}{|c|}{ Ukuran Saringan } & \multicolumn{2}{|c|}{$\begin{array}{c}\text { Titik Kontrol } \\
\text { Spesifikasi Bina } \\
\text { Marga } 2014(\%)\end{array}$} & \multirow[t]{2}{*}{$\begin{array}{l}\text { Kurva } \\
\text { Fuller }\end{array}$} & \multirow{2}{*}{$\begin{array}{c}\text { Gradasi } \\
\text { Ranca- } \\
\text { ngan } \\
\text { Pengujian } \\
(\%)\end{array}$} \\
\hline & (inch) & $(\mathrm{mm})$ & $\begin{array}{l}\text { Batas } \\
\text { Atas }\end{array}$ & $\begin{array}{c}\text { Batas } \\
\text { Bawah }\end{array}$ & & \\
\hline 1 & 1 & 25 & 100 & 100 & 100 & 100 \\
\hline 2 & $3 / 4$ & 19 & 100 & 90 & 87.8 & 95 \\
\hline 3 & $1 / 2$ & 12.5 & 90 & 75 & 73.3 & 82.5 \\
\hline 4 & $3 / 8$ & 9.5 & 82 & 66 & 64.2 & 74 \\
\hline 5 & 4 & 4.75 & 64 & 46 & 47.0 & 55 \\
\hline 6 & 8 & 2.36 & 49 & 30 & 34.5 & 39.5 \\
\hline 7 & 16 & 1.18 & 38 & 18 & 25.1 & 28 \\
\hline 8 & 30 & 0.6 & 28 & 12 & 18.5 & 20 \\
\hline 9 & 50 & 0.3 & 20 & 7 & 13.6 & 13.5 \\
\hline 10 & 100 & 0.15 & 13 & 5 & 9.9 & 9 \\
\hline 11 & 200 & 0.075 & 8 & 4 & 7.3 & 6 \\
\hline
\end{tabular}

\section{Recycle Concrete Aggregate}

Recycle Concrete Aggregate (limbah beton) adalah material beton yang sudah tidak terpakai lagi untuk konstruksi. Limbah beton yang akan digunakan dalam penelitian ini adalah limbah beton K-250 yang berasal dari laboratorium beton teknik sipil UniversitasTrisakti Jakarta. Berikut hasil penggujian 
dari Recycle Concrete Aggregate (RCA) dapat dilihat di Table 5.

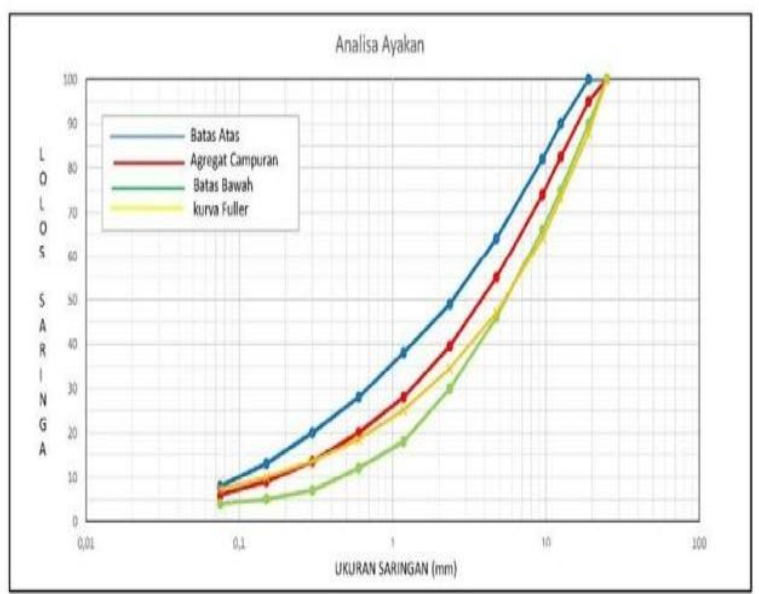

Gambar 3. Rancangan dan kurva gradasi

Tabel 5. Hasil Pemeriksaa RCA (Hasil penelitian dan Bina Marga, 2010, Revisi 3)

\begin{tabular}{|c|c|c|c|c|c|c|c|}
\hline No. & PENGUJAAN & METODA & \multicolumn{4}{|c|}{ HASIL PENGUJIAN } & $\begin{array}{c}\text { NILAI } \\
\text { PERSYAR } \\
\text { ATN BINA } \\
\text { MARGA } \\
2010\end{array}$ \\
\hline 1. & $\begin{array}{l}\text { Kekekalan bentuk agregat } \\
\text { terhadap lantan } \mathrm{NaSO4} \\
\text { atau MaSO4 }\end{array}$ & SNI 3407:2008 & \multicolumn{4}{|c|}{$4,69 \%$} & Maks. $12 \%$ \\
\hline 2. & $\begin{array}{l}\text { Abrasi dengan mesin Los } \\
\text { Angles }\end{array}$ & SNI 2417:2008 & \multicolumn{4}{|c|}{$17,63 \%$} & Maks. $30 \%$ \\
\hline 3. & $\begin{array}{lr}\text { Kelekatan } \\
\text { terhadap aspal }\end{array}$ & SNI $2439: 2011$ & \multicolumn{4}{|c|}{$98 \%$} & Min. 95\% \\
\hline 4. & $\begin{array}{l}\text { Butir Pecah Pada Agregat } \\
\text { Kasar }\end{array}$ & SNI 7619:2012 & \multicolumn{4}{|c|}{$95 \%$} & 95/90*) \\
\hline 5. & Partikel Pipih & & \multirow{2}{*}{\multicolumn{4}{|c|}{$\begin{array}{l}9,032 \% \\
9,31 \%\end{array}$}} & Maks. $10 \%$ \\
\hline \multirow{13}{*}{6.} & Partikel Kelonjongan & ASTM D479I & & & & & Maks. $10 \%$ \\
\hline & Berat Jenis & \multirow{12}{*}{$\begin{array}{c}\text { SNI 03-1969- } \\
1990\end{array}$} & Bulk & SSD & App & Abs & \\
\hline & Ukuran Saringan 1" & & 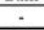 & - & - & - & \multirow{11}{*}{$\begin{array}{l}\text { - Absorbsi } \\
<3 \% \\
\text { - Perbedaan } \\
\text { agregat } \\
\text { kasar dan } \\
\text { agregat } \\
\text { halus } \\
<0,2 \%\end{array}$} \\
\hline & Ukuran Saringan 3/4" & & 2,50 & 2,54 & 2,62 & 1,94 & \\
\hline & Ukuran Saringan 1/2" & & 2,50 & 2,54 & 2,62 & 1,96 & \\
\hline & Ukuran Saringan $3 / 8^{\prime \prime}$ & & 2,53 & 2,58 & 2,66 & 1,98 & \\
\hline & Ukuran Saringan No. 4 & & 2,51 & 2,56 & 2,63 & 1,94 & \\
\hline & Ukuran Saringan No. 8 & & - & 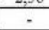 & - & - & \\
\hline & Ukuran Saringan No. 16 & & - & 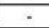 & - & . & \\
\hline & Ukuran Saringan No.30 & & - & - & - & 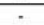 & \\
\hline & Ukuran Saringan No.50 & & - & - & $\cdot$ & 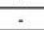 & \\
\hline & Ukuran Saringan No. 100 & & - & - & - & - & \\
\hline & Ukuran Saringan No. 200 & & - & - & - & - & \\
\hline
\end{tabular}

\section{METODE PENELITIAN}

Pengumpulan data pada penelitian ini dilakukan dengan cara percobaan yang dilakukan di beberapa laboratorium, seperti laboratorium Pusat Jalan Jembatan Bandung, laboratorium Institute Teknologi Bandung (ITB) dan laboratorium Universitas Trisakti Jakarta.

Sebelum masuk dalam pengujian modulus resilien maka dilakukan pengujian propestis dari masingmasing material, apabila pengujian material sudah sesuai oleh spesifikasi Bina Marga Tahun 2010 Divisi 6 (Revisi 3) maka dilakukan pengujian marshall, rendaman marshall dan kepadatan mutlak untuk mendapatkan kadar aspal optimum. Untuk pengujian modulus resilien total benda uji yang digunakan adalah 12 buah dimana untuk masingmasing temperatur $\left(25^{\circ} \mathrm{C}, 35^{\circ} \mathrm{C}\right.$ dan $\left.45^{\circ} \mathrm{C}\right)$ menggunakan 4 buah benda uji dengan presentase berbeda di setiap benda ujinya. Presentase di setiap benda uji berdasarkan pada komposisi limbahnya.
Untuk presentasenya yaitu $0 \%$ terhadap berat total agregat baru, 5\% terhadap berat total agregat baru, $10 \%$ terhadap berat total agregat baru dan $15 \%$ terhadap berat total agregat baru. Tahap pengetesan modulus resilien dengan cara memanaskan benda uji dalam ruang temperatur terkendali. Sebelum pengujian, dimensi benda uji yaitu tinggi dan diameternya sudah harus diketahui ukurannya. Jika data pengujian laboratorium tersebut sudah terkumpul, data tersebut akan langsung dianalisis untuk mengetahui pengaruh limbah beton pada campuran beraspal panas pada gradasi (AC-BC) terhadap nilai kekakuan. Gambar 2 menunjukkan benda uji modulus resulien. Gambar 3 menunjukkan alat pengujian modulus resilien yang berada di laboratorium Pusat Jalan Jembatan Bandung.

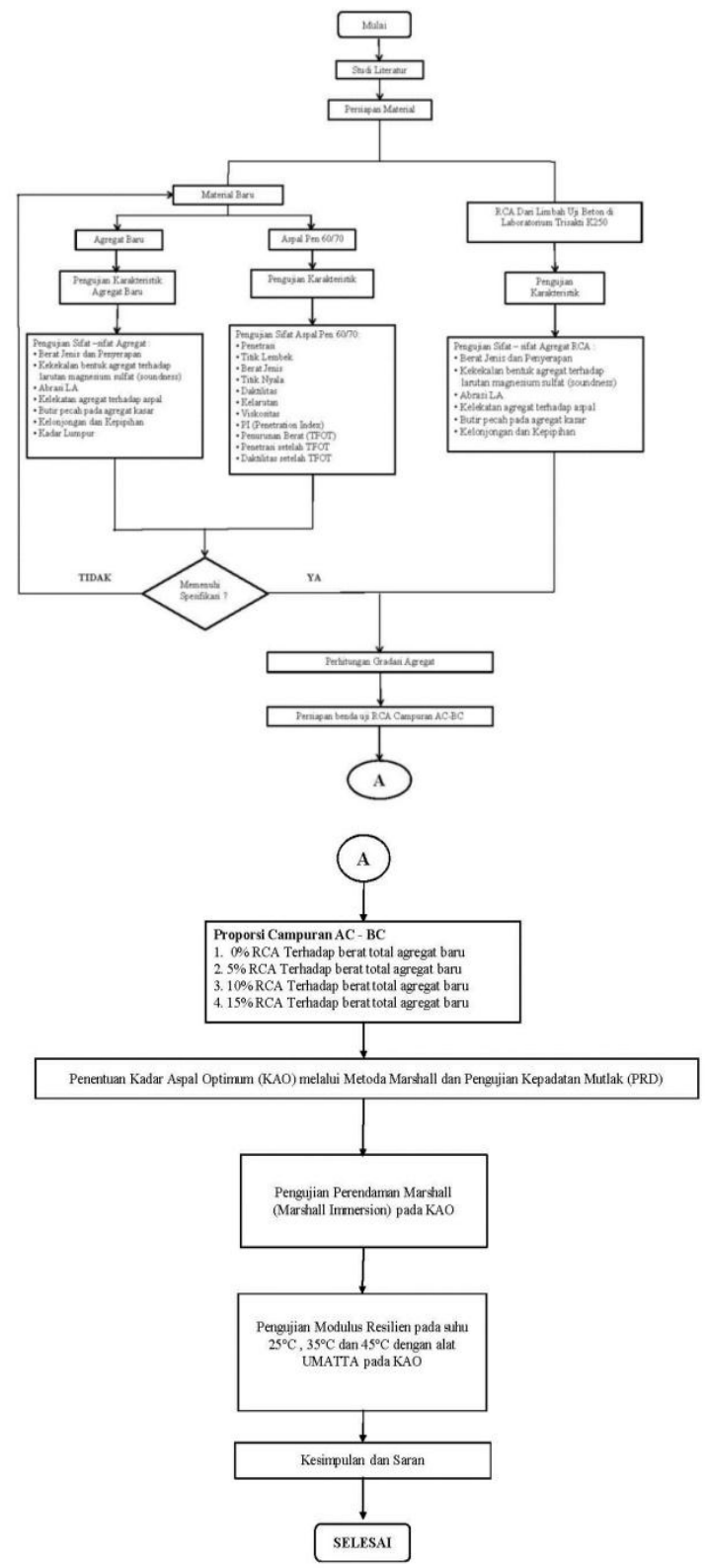

Gambar 4. Bagan Alir Penelitian 


\section{HASIL DAN PEMBAHASAN}

Hasil Pengujian campuran AC-BC dengan metode Marshall

Rendaman Marshall dan Kepadatan Mutlak. Untuk data dari pengujian Marshall, Rendaman Marshall dan Kepadatan mutlak diperoleh dari peneliti terdahulu (Galih, 2020). Pengujian Marshall, Rendaman Marshall serta Kepadatan Mutlak untuk digunakan sebagai penentuan Kadar Aspal Optimum (KAO) yang mana KAO tersebut digunakan sebagai persentase jumlah aspal yang digunakan. Persentase Kadar Aspal Optimum ditunjukkan di tabel 6.

Tabel 6. Kadar Aspal Optimum (KAO)

\begin{tabular}{ccc}
\hline NO. & KADAR RCA & KAO \\
\hline 1 & $0 \%$ & $5,29 \%$ \\
2 & $5 \%$ & $5,44 \%$ \\
3 & $10 \%$ & $5,77 \%$ \\
4 & $15 \%$ & $6,02 \%$ \\
\hline
\end{tabular}

\section{Hasil Penggujian Modulus Resilien}

Pengujian Modulus Resilien dilakukan dengan menggunakan alat UMATTA. Pengujian ini dilakukan di Laboratorium Bahan Jalan, Puslitbang Jalan dan Jembatan Kementerian Pekerjaan Umum. Pengujian dilakukan mengacu kepada ASTM D4123-82 Standart Test Method For Indirect Tension Test for Resilient Modulus of Bituminious Mixtures. Kondisi pengujian diatur pada loading pulse width $250 \mathrm{~ms}$, pulse repetition period 3000 ms. Temperatur pengujian dilakukan pada $25^{\circ} \mathrm{C}, 35^{\circ} \mathrm{C}$ dan $45^{\circ} \mathrm{C}$. Alat Universal Material Testing Apparatus (UMATTA) yaitu menggunakan benda uji diametral seperti benda uji Marshall dan dibuat pada Kadar Aspal Optimum (KAO). Hasil pengujian untuk ketiga jenis campuran pada temperatur $25^{\circ} \mathrm{C}, 35^{\circ} \mathrm{C}$ dan $45^{\circ} \mathrm{C}$. Hasil pengujian Modulus Resilien ditunjukkan pada Tabel 6 dan Grafik hasil pengujian ditunjukkan pdaa Gambar 4.

Tabel 7. Hasil Pengujian Modulus Resilien

\begin{tabular}{cccccc}
\hline \multirow{2}{*}{ No. } & Temp. Uji & \multicolumn{4}{c}{ Hasil Pengujian } \\
\cline { 3 - 6 } & & $0 \%$ & $5 \%$ & $10 \%$ & $15 \%$ \\
\hline 1 & 25 & 1933 & 2720 & 2416 & 2487 \\
2 & 35 & 597 & 817 & 663 & 616 \\
3 & 45 & 264 & 283 & 322 & 272 \\
\hline
\end{tabular}

Pada temperatur $25^{\circ} \mathrm{C}$ pada kadar limbah beton $0 \%$ nilai Modulus Resilien adalah 1933 Mpa dan terjadi kenaikan pada kadar limbah beton $5 \%$ yaitu $2720 \mathrm{Mpa}$, dan terjadi penurunan nilai Modulus Resilien pada kadar limbah beton $10 \%$ yaitu $2416 \mathrm{Mpa}$ dan terjadi kenaikan kembali nilai Modulus Resilien pada limbah beton15\% yaitu $2487 \mathrm{Mpa}$.

Pada temperatur $35^{\circ} \mathrm{C}$ pada kadar limbah beton $0 \%$ nilai Modulus Resilien adalah $597 \mathrm{Mpa}$ dan terjadi kenaikan pada kadar limbah beton 5\% yaitu $817 \mathrm{Mpa}$, dan terjadi penurunan nilai Modulus Resilien pada kadar limbah beton $10 \%$ yaitu $663 \mathrm{Mpa}$ dan kadar limbah beton $15 \%$ yaitu $616 \mathrm{Mpa}$.

Pada temperatur $45^{\circ} \mathrm{C}$ pada limbah beton $0 \%$ nilai Modulus Resilien adalah 246 Mpa dan terjadi kenaikan pada kadar limbah beton 5\% yaitu $283 \mathrm{Mpa}$, dan pada kadar limbah beton $10 \%$ yaitu $322 \mathrm{Mpa}$ dan terjadi penurunan pada kadar limbah beton $15 \%$ yaitu $272 \mathrm{Mpa}$

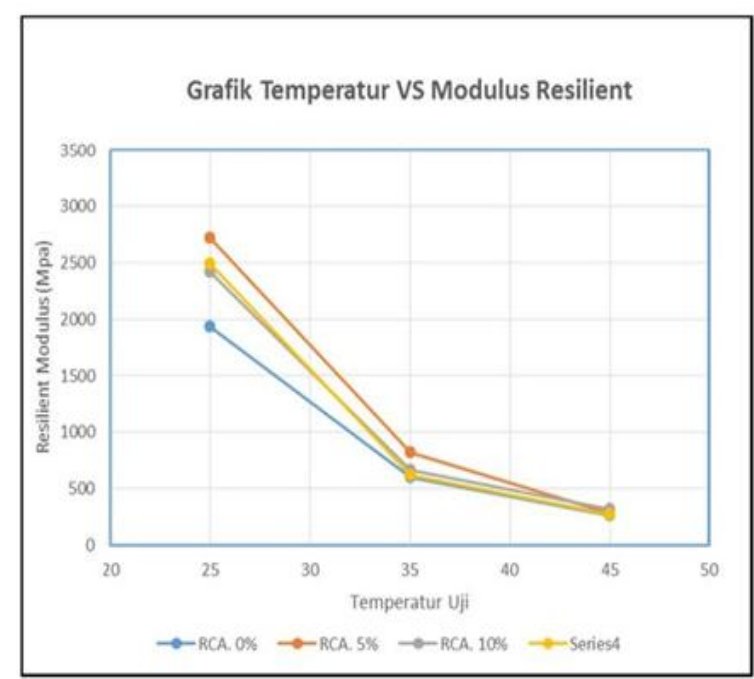

Gambar 4. Grafik Temperatur vs Modulus Resilien

Hasil pengujian untuk ketiga jenis campuran pada temperatur $25^{\circ} \mathrm{C}, 35^{\circ} \mathrm{C}$, dan $45^{\circ} \mathrm{C}$ ditunjukkan pada Tabel 6. Kenaikan kembali nilai Modulus Resilien pada RCA $15 \%$ yaitu $2487 \mathrm{Mpa}$. Pada temperatur $35^{\circ} \mathrm{C}$ pada kadar RCA 0\%, nilai Modulus Resilien adalah 597 Mpa dan terjadi kenaikan pada kadar RCA 5\% yaitu $817 \mathrm{Mpa}$, dan terjadi penurunan nilai Modulus Resilien pada kadar RCA 10\% yaitu 663 Mpa dan kadar RCA 15\% yaitu 616 Mpa. Pada temperatur $45^{\circ} \mathrm{C}$, kadar RCA $0 \%$ nilai Modulus Resilien adalah $246 \mathrm{Mpa}$ dan terjadi kenaikan pada kadar RCA 5\% yaitu $283 \mathrm{Mpa}$, dan pada kadar RCA $10 \%$ yaitu $322 \mathrm{Mpa}$ dan terjadi penurunan pada kadar RCA 15\% yaitu $272 \mathrm{Mpa}$. Apabila dilihat dari hasil nilai Modulus Resilien maka secara umum penambahan RCA dapat meningkatkan nilai modulus.

\section{KESIMPULAN DAN SARAN}

Berdasarkan hasil penelitian yang telah dilakukan dapat diambil sebuah kesimpulan bahwa nilai modulus resilien campuran AC-BC yang mengandung RCA lebih superior dibandingkan dengan tanpa RCA di tiga temperature pengujian yaitu $25^{\circ} \mathrm{C}, 35^{\circ} \mathrm{C}$, dan $45^{\circ} \mathrm{C}$.

Penelitian selanjutnya perlu melakukan evaluasi pengaruh RCA dari mutu beton yang berbeda dan dari bangunan beton yang sudah tidak terpakai (habis umur rencananya) serta melakukan pengujian kinerja ketahanan lelah (kuat fatique) dari campuran aspal panas AC-BC yang mengandung RCA.

\section{DAFTAR PUSTAKA}

Bethary, R. T. (2018). Campuran beraspal menggunakan reclaimed asphalt pavement dan agregat slag baja program doktor sistem dan teknik jalan raya (STJR). Institut Teknologi Bandung (ITB).

Subagyo, G. W. \& Indramaha (2020). Kinerja marshall campuran beraspal panas Asphalt Concrete Binder Course (AC-BC) mengandung Recycled Concrete Aggregate (RCA) 
Indramaha (2015). Perkembangan model modulus resilien dan kuat fatique dari campuran hangat $\mathrm{AC}$ lapis antara (AC-BC) memakai material RAP (Reclaimed Asphalt Pavement). Institut Teknologi Bandung (ITB).

Isyak, B. M. (2016). Analisa karakteristik marshall pada campuran asphalt concrete-binder course (AC-BC) menggunakan limbah beton sebagai coarse agregat. Universitas muhammadiyah Surakarta.

Hardiyatmo, H. C. (2011). Perancangan perkerasan jalan dan penyelidikan tanah. Gadjah Mada University Press, Yogyakarta.
Kementrian Pekerjaan Umum (2010). Spesifikasi umum 2010. Direktorat Jendral Bina Marga.

Kementrian Pekerjaan Umum (1999). Pedoman perencanaan campuran beraspal dengan pendekatan kepadatan mutlak. Direktorat Jendral Bina Marga

Soehartono (2015). Teknologi Aspal dan Penggunaannya dalam Konstruksi Perkerasan Jalan. Yogyakarta: Andi Offset.

Sukirman, S. (2003). Beton Aspal Campuran Panas. Jakarta: Granit. Sukirman, S. (1999). Perkerasan Lentur Jalan Raya, Bandung. 